\title{
MACHINE VS HUMAN TRANSLATION IN THE SYNERGETIC TRANSLATION SPACE
}

\author{
Natalia V. Sokolova \\ Perm National Research Polytechnic University, Perm, Russia
}

\begin{abstract}
The paper focuses on English-to-Russian translations of patent applications on the website of the World Intellectual Property Organization (WIPO). A comparative analysis of patent applications is performed by using translations made with the help of the WIPO Translate tool and human translators within the framework of the synergetic translation space concept encompassing the domains of the author's intensions, text content and composition, energy, translator, recipient, and the translation acceptability notion. The translation erratology aspects were considered from the point of view of the semantic, referential, and syntactic ambiguity within the domains of content-composition and energy space. In the domain of the author, the intention to convey some technical information is revealed, while its rendering in the content-composition and energy domains depends on whether the translation is made by a person or a machine. Genre- and composition-related specifics have been rendered in both cases while machine translation errors have been proven to result from the semantic, referential, or syntactic ambiguity, and this is when the translated output is generally considered unacceptable by the recipient. The results obtained can be used for editing machine translations of patent documentation, assessing the quality of technical documentation translation that is referred to other specific genre conventions.
\end{abstract}

Key words: patent application, machine translation, ambiguity, acceptability, editing, synergetic approach.

Citation. Sokolova N.V. Machine vs Human Translation in the Synergetic Translation Space. Vestnik Volgogradskogo gosudarstvennogo universiteta. Seriya 2. Yazykoznanie [Science Journal of Volgograd State University. Linguistics], 2021, vol. 20, no. 6, pp. 89-98. DOI: https://doi.org/10.15688/jvolsu2.2021.6.8

\section{МАШИННЫЙ ПЕРЕВОД VS ПЕРЕВОД, ВЫПОЛНЕННЫЙ ЧЕЛОВЕКОМ, В СИНЕРГЕТИЧЕСКОМ ПЕРЕВОДЧЕСКОМ ПРОСТРАНСТВЕ}

\author{
Наталья Владимировна Соколова \\ Пермский национальный исследовательский политехнический университет, г. Пермь, Россия
}

\begin{abstract}
Аннотация. В статье на материале патентных заявок, представленных на веб-сайте Всемирной организации интеллектуальной собственности (WIPO), рассматриваются лингвистические проблемы перевода с английского языка на русский. Осуществлен сопоставительный анализ переводов патентных заявок, выполненных с помощью инструмента WIPO Translate и человека, в рамках синергетической концепции переводческого пространства, включающей поля автора, содержания и композиции, переводчика, реципиента, а также энергетическое поле, и опирающейся на понятие приемлемости перевода. Эрратологические аспекты перевода охарактеризованы с точки зрения смысловой, референциальной и синтаксической неоднозначности в рамках содержательного, композиционного и энергетического полей. Установлено, что в переводах, выполненных машиной и человеком, в поле автора патентной заявки реализуется намерение передать техническую информацию. Показано, что в содержательном, композиционном и энергетическом полях жанрово-композиционные особенности заявки переданы в переводах обоих типов, а при наличии в оригинале смысловой, референциальной или синтаксической неоднозначности в машинном переводе присутствовали ошибки, а текст перевода воспринимался реципиентом как неприемлемый. Результаты исследования могут быть использованы при редактировании машинных переводов патент(2) ной документации, а также при оценивании качества перевода технической документации других жанров.
\end{abstract}


Ключевые слова: патентная заявка, машинный перевод, неоднозначность, приемлемость, редактирование, синергетический подход.

Цитирование. Соколова Н. В. Машинный перевод vs перевод, выполненный человеком, в синергетическом переводческом пространстве // Вестник Волгоградского государственного университета. Серия 2, Языкознание. - 2021. - Т. 20, № 6. - С. 89-98. - (На англ. яз.). - DOI: https://doi.org/10.15688/jvolsu2.2021.6.8

\section{Introduction}

The role of technical texts, or texts pertaining to the subject area of technology [Lotman, 2000; 2010, p. 67] and conveying respective information, is becoming increasingly important.

Currently, we are witnessing an unprecedented growth of technical information an umbrella term describing any technology-related data such as technical know-how, standards and specifications, invention and innovation disclosures, patent applications and drawings, manuals, etc. For example, the number of patent applications worldwide has demonstrated a three-fold increase within the period of 2002-2016, according to the World Intellectual Property Organization (WIPO). Pertaining to the domain of technology [Lotman, 2010 , p. 17], technical texts play their role in disseminating specific technical knowledge.

Technical information can be further disseminated through translation into other languages. The amount of technical translation accounts for a great proportion of the world's translation output [Franco Aixelá, 2004].

Moreover, technical translation itself often involves utilizing technology. One cannot but witness a growing tendency to have technical texts - such as patent applications - translated via a variety of machine translation tools powered by IT giants.

The intricacies of technical translation have been approached by scholars, with lexical aspects [Shershukova, 2017; Trinozhenko, Goncharova, 2016] or the translator being in focus [Fontanet, 2016], etc. Speculations about the pros and cons of machine vs. human translation are also underway [Zhaorong Zong, 2018].

Within the domain of linguistics, the wordsense, referential, and syntactic ambiguity types have been proven to be the reason behind machine translation errors [Linares, 2008] (see also: [Sokolova, 2019]) which can be explained by the fact that words may have more than one meaning, referent, and can be used in complicated syntactic structures [Linares, 2008, p. 3].
These findings focus on the linguistic material and its translated output leaving the process of translation and its stakeholders behind, along with genre-related aspects. These assumptions make us believe that a broader approach should be applied to human-produced and machine translations of technical texts within the area of translation studies.

This paper does not intend to unravel the misconceptions intertwined with technical translation and brilliantly exposed by Jody Byrne [Byrne, 2004; 2006] such as those of technical translation including economics, law, business etc. and being a non-creative transfer process [Byrne, 2006].

Investigating the technical translation process within a framework embracing the stakeholders and the output of technical translation produced by humans and machines, the paper aims at comparing such output in terms of acceptability.

\section{Material and methodology}

When it comes to technical texts, patent documents are of particular interest as they deliver cutting-edge technical knowledge. The European Patent Office (EPO), the United States Patent and Trademark Office (USPTO) are among the institutions accumulating and disseminating patent data. The World Intellectual Property Organization (WIPO) maintains a special database PATENTSCOPE (WIPO PATENSCOPE) providing access to over 90 million patent documents and 4 million published international patent applications regardless of country specifics. In addition, the WIPO provides database users with a custom machine translation tool - WIPO Translate.

The paper draws on the English language patents of the WIPO PATENTSCOPE database as the material of the study in the amount of 120,000 characters and their human-produced and machine translations into Russian. The machine translations coming under scrutiny are generated using the custom WIPO Translate tool specifically 
trained in the subject area of patents. Human translations were made by professional translators. The English language patents under study pertain to the subject area of information technology and related embodiments in the linguistic field.

According to the WIPO maintaining the PATENTSCOPE database, a technology patent "is an exclusive right to a product or a process that generally provides a new way of doing something or offers a new technical solution to a problem. To get a patent, technical information about the invention must be disclosed to the public in a patent application" (FAQ).

Since the technical translation process involves several stakeholders, and the relevant information should be taken into account, the synergetic translation space approach elaborated by L.V. Kushnina [Kushnina, 2004] might have a potential of explaining the complex process of any translation type, including the technical one.

We assume that this all-encompassing synergetic translation space approach could provide for investigating the technical translation process within the framework of the domains outlined below:

- the author's domain conveying the intention of the author to render some information in a particular way;

- the composition- and content-related domain which contains terms while their adequate translation ensures the successful transposition of factual meanings; the word-sense, referential, and syntactic ambiguity will come under scrutiny in this respect;

- the energy-related domain of technical texts containing both verbal means such as official clichés rendering emotive meanings and nonverbal means including figures, drawings, etc. [Ketola, 2015];

- the translator's domain which is intertwined with the translator's understanding of the author's intention to be eventually transposed to and embodied in the target text;

- the recipient's domain within which the target text becomes part and parcel of the recipient's culture [Kushnina, 2013] (see also: [Larson, 1987]).

This approach provides for transposing factual and emotive meanings of the source text and transplanting them into the target text and culture
[Kushnina, 2004]. The target text should not be identical to the source one; it must sound natural instead [Kushnina, 2013] being acceptable to the target culture.

The paper also makes use of terms such as word-sense ambiguity, with "words having more than one possible meaning or sense" [Linares, 2008, p. 3; Miftakhova, 2017]; referential ambiguity for words having more than one referent [Linares, 2008, p. 3]; and syntactic ambiguity [Linares, 2008, p. 3], which may result in translation errors.

This is when the notion of acceptability should be emphasized as "subscription to norms originating in the target culture determines... acceptability" [Toury, 1995, p. 57].

J. Byrne stresses that the aim of technical translation is to achieve a high level of acceptability because technical texts are intended to function as a target language text [Byrne, 2006, p. 37] while M. Larson points out that "the goal of most translators is to produce translations which are acceptable for the audiences for whom the translations are produced" [Larson, 1987, p. 69].

It is also of crucial importance within the context of this paper to focus on the notions of text and genre as "at a general level, text refers to a sequence of sentences serving an overall rhetorical purpose... genre refers to the conventional linguistic expression associated with speech and writing in certain contexts of situation (e.g. the letter to the editor)" [Baker, Saldanha (eds.), 2011, p. 89]. Ultimately, genres demonstrate definite and relatively stable typical forms as a whole [Bakhtin, 1986].

Patents constitute a genre of their own which makes it possible for us to investigate both the conventional expressions of the patent genre and their textual realization from the perspective of the translation space approach both in the source and target texts of information technology patent documents translated by humans and with the help of the WIPO Translate tool.

Thus, the methodology framework to be applied to human and machine translations of patent documents provides for:

1) selecting patent documents and having them translated both with the help of human translators and the WIPO Translate tool;

2 ) investigating the source and target texts both machine- and human-produced ones - within 
the domains of the author, content, energy, translator, recipient;

3) comparing the machine- and humanproduced translation output in terms of its acceptability.

\section{Results and discussion}

\section{The author's domain}

First of all, translation can be generally perceived as a communicative act involving the author, the translator, and the reader [Byrne, 2006, p. 11] so it is the intention [Klushina, 2012] of the author that is crucial in generating the source text and determining its function.

The author's intention to present technical information of patent documents results in their primarily informative function, but "there is more to technical translation than simply transmitting information. Instead, the challenge for technical communicators is to ensure that all the relevant information is indeed conveyed but also that it is conveyed in such a way that the readers can use the information easily, properly and effectively" [Byrne, 2006, p. 10]. "...The sole purpose is to communicate technical information clearly and efficiently" [Byrne, 2006, p. 175].

Thus, the author's intention determines the informative function of technical texts such as patent documents and - respectively - technical translation as a process of communicating relevant information and its resulting output.

\section{The composition and content domain}

The intention of the author's domain to provide new technical information clearly and precisely manifests itself in a specific content of patent documents within the framework of the genre-specific composition.

Typically, the genre of patents has conventional composition parts such as summary, related applications, technical field, background art which can be rendered into Russian as peфpepam, родственные заявки, область техники / технического применения, уровень техники, respectively.

The invention summary gives a general description while the brief description of the drawings (описание чертежей) and description of specific embodiments (onucaние внедрений) focus on drawings and invention applications. Via Claims (формула изобретения), one can get familiarized with methodological guidelines. Eventually, the parts of patent applications work together to deliver all the relevant technical information both in the verbal and nonverbal forms such as drawings and figures, with the titles of the patent parts being conventionally translated into Russian as specified above.

The custom WIPO tool trained to translate patent documents demonstrates that it can handle the challenges of choosing the proper word within the patent subject area when it comes to genrespecific titles as can be seen in the machine translations below since the technical field and background are rendered as область техни$\kappa и$ и уровень техники in line with the genrespecific clichés accepted in the Russian technical language and culture:

\section{(1) TECHNICAL FIELD}

The present disclosure is generally related to computer systems, and is more specifically related to systems and methods for automated translation of electronic documents from one or more source natural language to one or more target natural languages.

\section{Machine translation: Область техники}

Настоящее раскрытие в целом относится к компьютерным системам и, более конкретно, относится к системам и способам автоматического перевода электронных документов из одного или более источников естественного языка на один или более целевых естественных языков.

\section{(2) BACKGROUND}

Language translation computer programs perform reasonably well for formal content in wellstudied languages (e.g., English, French, Spanish, German, and others). However, for other language, as well as informal or subject area-specific content, a user has often resort to human translation and hence bear the associated costs (US20160259760).

\section{Machine translation: Уровень техники}

Компьютерные программы машинного перевода достаточно хорошо работают для формального содержания на хорошо изученных языках (например, английский, французский, испанский, немецкий и другие). Однако для другого языка, а также неформального или тематически определенного содержания, пользователь часто прибегает к трансляции человека и, следовательно, поддерживает связанные с ними затраты. 
At the same time, the machine translation excerpt (2) above demonstrates the wrong and non-acceptable rendering of the term human translation as транслячия человека instead of перевод, выполненный человеком.

This fact shows that polysemantic words and their word-sense ambiguity as well as the proper choice of factual meanings still pose a major challenge even to genre-trained machine translation tools. As for those conventional genre-specific clichés such as titles of patent sections, the machine can easily and errorfree replace them with their Russian equivalents within the context of the patent genre.

The author's intention to describe the invention in the most detailed and precise manner could also result in using terms in the form of multi-component collocations [Vlavatskaya, 2011, p. 135] when end words are preceded with other ones, for example, a Web search engine user interface; an enterprise cloud computing platform; the search engine user interface, etc. (WO2017151408). As a result, translators deal not only with rendering the meanings of terms but also with challenges of disentangling multi-component collocations and their syntactic relations.

The patent document (WO2017034824) below features a variety of multi-component collocations such as the source language, the target language, web pages, a web page copy, the human translators translations, etc. There are also attributes such as participles and clauses identifying these nouns in detects a second request for the web page from a computing device associated with the target language and in response to detecting the second request outputs to the computing device the translated web page with additional content (WO2017034824). One can come across subordinate clauses such as while machine translation is typically faster and less expensive, manual translation can typically provide higher quality translations (WO2017034824).

Below are the analyzed excerpts translated by a human translator and rendered with the help of the WIPO Translate tool, respectively:

(3) In response to receiving a first request to opt in to the translation feature the server: detects a second request for the web page from a computing device associated with the target language and in response to detecting the second request outputs to the computing device the translated web page with additional content relevant to the computing device or a user associated with the computing device (WO2017034824).

Human translation: В ответ на получение первого запроса на выполнение перевода сервер: отслеживает второй запрос веб-страницы, поступающий от компьютерного устройства, связанного с работой на языке перевода, и в ответ на второй полученный запрос загружает на устройство переведенную веб-страницу с дополнительной информацией, относящейся к устройству или пользователю устройства.

Machine translation: В ответ на прием первого запроса на выполнение перевода сервер: обнаруживает второй запрос web-cmpaницы из вычислительного устройства, связанного с целевым язы$\boldsymbol{\kappa o \boldsymbol { m } , ~ и ~ в ~ о т в е т ~ н а ~ о б н а р у ж е н и е ~ в т о р ы х ~ з а п р о с о в ~}$ запроса на вычислительное устройство передает переведенную web-страницу с дополнительным содержанием, релевантным для вычислительного устройства, или пользователя, ассоциативно связанного с вычислительным устройством.

The comparison of the human and machine translations above makes it evident that the content-related domain is rendered in the machine translation output improperly as the multi-component term target language conventionally translated into Russian as язык перевода is conveyed as целевой язык. At the same time, it is also of particular interest that the term иелевой язык is becoming more pervasive these days as compared to the traditional term язык перевода.

The referential and syntactic ambiguity is also a challenge, with the part additional content relevant to the computing device or a user associated with the computing device rendered as дополнительным содержанием, релевантным для вычислительного устройства, или пользователя, ассочиативно связанного $\mathrm{c}$ вычислительным устройством. In comparison, the human translation output above demonstrates a variety of techniques relevant in the context which make the resulting output acceptable.

The next example below demonstrates again that the machine translation tool fails to render the terms due to the word-sense and referential ambiguity, with manual translation being conveyed as ручная трансляция, while the human translator opted for using the antonymous translation немашинный перевод: 
(4) While machine translation is typically faster and less expensive, manual translation can typically provide higher quality translations (WO2017034824).

Machine translation: Хотя машинное преобразование обычно является более быстрым и менее дорогостоящим, ручная трансляция может, как правило, предоставлять переводы более высокого качества.

Human translation: Несмотря на то, что маиинный перевод чаще оказывается быстрее и дешевле, немашинный, как правило, отличается более высоким качеством.

One cannot but conclude that the acceptability is not the case when terms and multi-component collocations within the contentrelated domain of patent documents are translated using machine tools as opposed to and compared with translations made by humans. Machines are "baffled" by the word-sense ambiguity [Linares, 2008] of terms in the context such as translation - перевод - трансляичя, machine translation - машинный перевод машинная трансляичя, etc., with this type of ambiguity being the result of using "words having more than one possible meaning or sense" [Linares, 2008, p. 3; Miftakhova, 2017].

The author's intention to define the notions as comprehensively and precisely as possible also results in using descriptive participles and clauses, for example:

(5) Also presented are a server having one or more processors configured to perform operations and a computer-readable medium...

Machine translation: Также представлены сервер, имеющий один или более процессоров, сконфигурированных для выполнения операций, и машиночитаемый носитель...

And the machine translation above demonstrates the fact that this type of the syntactic ambiguity is an obstacle overcome since the linear syntactical structures of patent texts can be easily transposed to the target language.

Thus, the conventional titles of patent parts background, summary, etc. - can be rendered equally acceptably both by humans and the WIPO Translate tool trained using the patent genre features. This statement is also true of syntactic structures consisting of nouns and identified with participles and clauses which are typical of the patent genre.
However, when it comes to the ambiguity of polysemantic words and the referential ambiguity in the patent texts, the machine translation tool happens to be incapable of choosing the proper factual meaning in the context while the human translator makes proper choices.

\section{The energy domain}

There is a stereotype that patents deliver information in the most impassionate way, and it turns out to be untrue when taking a closer look at the conventional composition of patent applications and their textual content.

As mentioned earlier, the Background section of patent applications describes the problem associated with the current state of technology which might be too slow, too expensive, not easy to use, etc. This is when the proposed invention is supposed to be helpful in solving this problem. And this is when the emotive meanings may come forward in the Background section due to conveying the persuasive intention of the author and setting the positive tonality [Matveeva, 2006] of the section offering some cutting-edge solution to the problem specified.

The analysis of the patent document below (US20120215521) shows that the Background section can be built around the antithesis of the prior, present, and the future state of things, with the prior or present ones being problematic and the invention method being effective, accurate, necessary, enabling users to clearly and easily communicate, etc. The emotive words can also be accompanied by intensifiers such as highly, etc.:

(6) The present invention is a software application that is designed to allow individuals, who speak different languages, to clearly and easily communicate with each other. $<$... $>$ Users may speak or type messages with the software application and then press a "translate" button to select a language in order to send the message in that language. $<\ldots>$

Many individuals find themselves in situations that require knowledge of other languages. While vacationing, working, or visiting areas in which the native language is unfamiliar, individuals may find themselves unable to communicate with the people around them. This can be highly problematic, especially if these individuals become lost, are sent to 
the hospital, or find themselves in other emergency situations (US20120215521).

Machine translation: Настоящее изобретение представляет собой приложение программного обеспечения, которое предназначено для того, чтобы дать возможность людям, которые говорят на разных языках, ясно и легко связываться друг с другом. Пользователи могут говорить или тип сообщений с приложением программного обеспечения и затем нажать кнопку “транслировать” для того, чтобы выбрать язык для того, чтобы послать сообщение на этом языке.

Многие люди находят себя в ситуациях, которые требуют знания других языков. В то время как истощение, обработка или посещающие области, в которых родной язык неизвестны, индивидуумы могут найти себя неспособным связаться с людьми вокруг них. Это может быть весьма проблематичным, особенно если эти люди потеряны, отправлены в больницу или находят себя в других чрезвычайных ситуациях.

Human translation: Настоящее изобретение представляет собой программное приложение, которое предназначено для того, чтобы предоставить возможность людям, говорящим на разных языках, легко общаться и понимать друг друга. < ..> Пользователи могут произнести или напечатать сообщение, а затем нажать кнопку «перевод», чтобы выбрать язык и отправить сообщение на этом языке. <...>

Многие оказываются в ситуациях, когда необходимо знание языков. В отпуске, на работе либо при посещении территорий, где говорят на неизвестном языке, люди не могут вступить в общение с окружающими. Это может быть весьма проблематичным, особенно если человек заблудился, попал в больницу или оказался в чрезвычайной ситуации.

The patent excerpts above feature qualitative adjectives and adverbs such as easily and highly problematic among others, which may not be considered typical of 'dry' technical texts. However, within this context, such words serve to render the persuasive intention of the author trying to provide some substantiation for the invention. To describe the current situation, the negatively-charged adjective highly problematic is used while the positively-charged one - easily - demonstrates the benefits of the solution described in the patent document.

As it turns out, all the qualitative adjectives and adverbs of the energy domain are rendered properly both in the human and machine translations since they have the literal meaning easy which means легкий, etc. in this context.

However, acceptability is not achieved in the content-related domain of the machine translation due to numerous errors resulting from the worldsense and syntactical ambiguity whereas vacationing, working, or visiting areas are translated as истощение, обработка или посещуающие области, etc.

This is also true of one more manifestation of the energy field in patent documentation such as metaphorical idioms. For example, the idiom word of mouth - the verbal sharing of information (Free Dictionary) - is used for describing aspects of creating patent databases as a result of word-of-mouth referrals. The machine translation (7) where this idiom is rendered as слов-референтов в ротовой полости is unacceptable:

(7) Physicians typically derive their patient base from word-of-mouth referrals. These word of mouth referrals generally come from former patients (WO2001035275).

Machine translation: Врачи, как правило, получают свое основание пациента из слов-референтов в ротовой полости. Эти слова, относящиеся к рту, как правило, поступают от прежних пациентов. Таким образом, врачи зависят от пациентов при построении основы пациента.

Human translation: Как правило, база пациентов врачей-терапевтов формируется на основании устных рекомендаций, которые предоставляют бывшие пациенты.

As compared to the machine translation above, the human-produced translation demonstrates a completely different picture, with the idiom rendered properly.

\section{The translator's and the recipient's domains}

The examples evidence the fact that it is the human translator who is capable of assembling and making sense of all the domains of the author's intention, genre composition and terminology content, as well as the emotive energy in order to deliver an acceptable translation output.

To assess such acceptability from the point of view of the recipient, a questionnaire was created and shown in a table below. With two 
translators in the area having been questioned to range these translations within the acceptablepartly acceptable - unacceptable criteria:

\begin{tabular}{|c|c|c|}
\hline $\begin{array}{c}\text { Target patent } \\
\text { application translation }\end{array}$ & Human & Machine \\
\hline Content domain & Acceptable & Unacceptable \\
\hline Composition domain & Acceptable & Acceptable \\
\hline Energy domain & Acceptable & $\begin{array}{c}\text { Partly acceptable/ } \\
\text { Unacceptable }\end{array}$ \\
\hline
\end{tabular}

As it follows from the table, the answers are identical when it comes to the content and composition domain. As for the energy domain, the answers range from partly acceptable to unacceptable providing assessments to the translation of separate emotive words such as highly problematic and idioms.

The machine translations under study lack acceptability mostly in the domains of rendering the author's intention, terminology content, and energy since the translation is a purposeful activity [Nord, 1997] - being far from a mere and primitive word-by-word substitution.

Undeniably, the machine translation tool under study shows progress in conveying the conventional translations of the genre-specific titles and linear syntactical structures along with single emotive words such as adjectives and adverbs while the idioms and culture-acceptable use of words leave the software tool 'baffled'.

\section{Conclusion}

Patent documents account for a great proportion of technical translation, with machine translation tools often touted as providing a solution, which the recipient might need in terms of getting comprehensible information. However, the translations produced by the WIPO Translate tool demonstrate that the machine translations of patents contain errors resulting from the semantic, referential, and syntactic ambiguity as compared to the patent translations made by humans. The premises come from the comparative analysis of the machine and human patent translations that was performed within the framework of the synergetic translation space concept, spanning the domains of the author, content and composition, energy, translator, recipient, and acceptability.

The synergetic translation space approach proved to be instrumental in unraveling the myth of coming-to-rescue machine translation since despite the progress made - only purposefully produced human translations demonstrate a viable potential of delivering the target culture-acceptable output fitting within all the translation domains of the author, composition, content, energy, and recipient and delivering their synergy while the machine translation tool can handle the process only within the conventional aspects of the patent genre composition. Assessing acceptability of rendering pointed to certain disparity in the contentcomposition and energy domains, as the technical and emotive information encoded by the author is delivered more accurately by a human translator. Genre- and composition-related specifics have been rendered in both cases while the machine translation errors in the content and energy domains have been proven to result from the semantic, referential, or syntactic ambiguity, and this is when the translated output is generally considered unacceptable by the recipient.

The outlined findings could be instrumental in paving the way for improving machine translation quality and acceptability as perceived by human recipients.

\section{REFERENCES}

Bakhtin M.M., 1986. Problema rechevykh zhanrov [The Problem of Speech Genres]. Estetika slovesnogo tvorchestva [The Aesthetics of Verbal Creativity]. Moscow, Iskusstvo Publ., pp. 250-296.

Baker M., Saldanha G., eds., 2011. Routledge Encyclopedia of Translation Studies. London and New York, Routledge, Taylor and Francis Group. 22. 674 p.

Byrne J., 2004. Textual Cognetics and the Role of Iconic Linkage in Software User Guides. Doctoral Dissertation. Dublin, Dublin City University. $357 \mathrm{p}$.

Byrne J., 2006. Technical Translation. Usability Strategies for Translating Technical Documentation. Netherlands, Springer, 13.280 p.

Fontanet M., 2003. The Technical Translator: The Sherlock Holmes of Translation? ATA Chronicle, 2013, July, vol. 42, no. 7, pp. 18-26. URL: https:// www.ata-chronicle.online/wp-content/uploads/ 4207_18_mathilde_fontanet.pdf (accessed 28 November 2020).

Franco Aixelá J., 2004. The Study of Technical and Scientific Translation: An Examination of Its Historical Development. Journal of Specialised Translation, no. 1, pp. 29-49. 
Ketola A., 2015. Translation Diaries of an Illustrated Technical Text. Connexions International Professional Communication Journal, no. 3 (2), pp. 13-40.

Klushina N.I., 2012. Intentsionalnyi metod v sovremennoi lingvisticheskoi paradigm [Intentional Method in the Modern Linguistic Paradigm]. Mediastilistka [Mediastylistics], iss. 4. URL: http://mediascope.ru/node/1242 (accessed 10 January 2021).

Kushnina L.V., 2004. Vzaimodeistvie yazykov i kultur $v$ perevodcheskom prostranstve: geshtaltsinergeticheskii podkhod: dis.... d-ra filol. nauk [The Interaction of Languages and Cultures in the Translation Space: The Gestalt-Synergetic Approach. Dr. philol. sci. diss.]. Perm. 437 p.

Kushnina L.V., 2013. Funktsionirovanie tekhnicheskikh tekstov v perevodcheskom prostranstve [The Functioning of Technical Texts in the Translation Space]. Filologicheskie nauki. Voprosy teorii $i$ praktiki [Philological Sciences. Issues of Theory and Practice], no. 11 (29), part 2, pp. 119-121.

Larson M., 1987. Establishing Project-Specific Criteria for Acceptability of Translations. Rose M.G., ed. Translation Excellence: Assessment, Achievement, Maintenance. American Translators Association Scholarly Monographs. Binghamton, New York, University Center, State University of New York, pp. 69-76.

Linares J.A.G., 2008. Empirical Machine Translation and Its Evaluation. Doctoral Dissertation. Barcelona. 247 p.

Lotman Yu.M., 2000. Semiosfera [Semiosphere]. Saint Petersburg, Iskusstvo-SPB Publ. 704 p.

Lotman Yu.M., 2010. Nepredskazuemye mekhanizmy kultury [Unpredictable Mechanisms of Culture]. Tallinn, TLU Press. 232 p.

Matveeva T.V., 2006. Tekstovaya kategoriya [Textual Category]. Kozhina M.N., ed. Stilisticheskii entsiklopedicheskii slovar russkogo yazyka [The Stylistic Encyclopedic Dictionary of the Russian Language]. Moscow, Flinta Publ., Nauka Publ., pp. 549-552.

Miftakhova R.G., 2017. Formalizatsiya estestvennogo yazyka $v$ mashinnom perevode s oporoi na dopolnitel'nyi korpus rodstvennogo yazyka: dis. ... kand. filol. nauk [Formalizing the Natural Language Using the Additional Corpus of the Related Language. Cand. philol. sci. diss.]. Ufa. 187 p.

Nord C., 1997. Translating As a Purposeful Activity. Manchester, St. Jerome Publishing. 154 p.

Shershukova N.V., 2017. Spetsifika perevoda nauchnykh i tekhnicheskikh tekstov (patentov) [Specifics of Translating Scientific and Technical Texts (Patents)]. Filologicheskie nauki. Voprosy teorii i praktiki [Philological Sciences. Issues of Theory and Practice], no. 3 (69), part 2, pp. 182-184.

Sokolova N.V., 2019. Mashinnyi perevod patentov: tipichnye oshibki [Machine Patent Translation: Typical Errors]. Mezhkulturnaya kommunikatsiya: lingvisticheskie aspekty: sb. materialov VIII Mezhdunar. nauch.-prakt. konf. (28-29 marta $2019 \mathrm{~g}$.) [Intercultural Communication: Linguistic Aspects. Proceedings of the $8^{\text {th }}$ International Scientific and Practical Conference (March 28-29, 2019)]. Novosibirsk, Novosibirskiy gosudarstvennyi tekhnicheskiy universitet, pp. 173-178.

Toury G., 1995. Descriptive Translation Studies and Beyond. Amsterdam, Philadelphia, John Benjamins. $311 \mathrm{p}$.

Trinozhenko M.D., Goncharova Yu.L., 2016. Spetsifika perevoda patentnoi dokumentatsii [Specifics of Translating Patent Documents]. Yunyi issledovatel Dona [Don's Young Researcher], no. 1 (1), pp. 1-6.

Vlavatskaya M.V., 2011. Teoreticheskie problemy kombinatornoi lingvistiki. Leksikologiya. Leksikografiya [Theoretical Issues of Combinatorial Linguistics. Lexicology. Lexicography]. Novosibirsk, NGTU. 508 p.

Zhaorong Zong, 2018. Research on the Relations Between Machine Translation and Human Translation. Journal of Physics: Conferences Series, vol. 1087, iss. 06, pp. 1-6. DOI: 10.1088/ 1742-6596/1087/6/062046.

\section{SOURCES}

EPO - European Patent Office. URL: https:// www.epo.org/ (accessed 10 January 2021).

$F A Q$ - Frequently Asked Questions: Patents. URL: https://www.wipo.int/patents/en/faq_ patents.html (accessed 10 January 2021).

Free Dictionary - Free Dictionary. URL: https://idioms. thefreedictionary.com/word-of-mouth (accessed 10 January 2021).

USPTO - United States Patent and Trademark Office. URL: https://www.uspto.gov/patents-applicationprocess/search-patents (accessed 10 January 2021).

US20120215521 - Software Application Method to Translate an Incoming Message, an Outgoing Message, or a User Input Text // WIPO PATENSCOPE. URL: https://patentscope. wipo.int/search/ru/detail.jsf?docId= US74346340\&tab= PCTDESCRIPTION\&_cid= P10-K1QKXL-27077-1 (accessed 10 January 2021).

US20160259760 - Automated Document Translation // WIPO PATENSCOPE. URL: https:// 
patentscope.wipo.int/search/ru/detail.jsf? docId $=$ US177603917\&tab=PCTDESCRIPTION\& cid=P10-K3G6FH-49819-2 (accessed 10 January 2021).

WO2001035275 - Building Metaphor // WIPO PATENSCOPE. URL: https://patentscope. wipo.int/search/en/detail.jsf?docId= WO2001035275\&_cid=P20-KJRFXZ-74690-1 (accessed 10 January 2021).

WO2017034824 - Techniques for Crowd Sourcing Human Translations to Provide Translated Versions of Web Pages with Additional Content // WIPO PATENSCOPE. URL: https:// patentscope.wipo.int/search/ru/detail.jsf?
docId=WO2017034824\&_cid=P10-K3D8ET84783-1 (accessed 10 January 2021).

WO2017151408-Blending Enterprise Content and Web Results // WIPO PATENSCOPE. URL: https:// patentscope.wipo.int/search/ru/detail.jsf?docId= WO2017151408\&tab=PCTBIBLIO\&_cid=P20JY16IZ-51668-1 (accessed 10 January 2021).

WIPO - World Intellectual Property Organization. URL: https://www.wipo.int/edocs/pubdocs/en/ wipo_pub_941_2017-chapter2.pdf(accessed 10 January 2021).

WIPO PATENTSCOPE - WIPO PATENTSCOPE. URL: https://www.wipo. int/patentscope/en/ (accessed 10 January 2021).

\section{Information About the Author}

Natalia V. Sokolova, Candidate of Sciences (Philology), Assistant Professor, Department of Foreign Languages, Linguistics and Translation, Perm National Research Polytechnic University, Prosp. Komsomolsky, 29, 614990 Perm, Russia, ntlk0@mail.ru, https://orcid.org/0000-0003-0550-2272

\section{Информация об авторе}

Наталья Владимировна Соколова, кандидат филологических наук, доцент кафедры иностранных языков, лингвистики и перевода, Пермский национальный исследовательский политехнический университет, просп. Комсомольский, 29, 614990 г. Пермь, Россия, ntlk0@mail.ru, https://orcid.org/0000-0003-0550-2272 